\title{
In-vitro Biological Evaluation of a Fabricated Polycaprolactone/Pomegranate Electrospun Scaffold for Bone Regeneration
}

\author{
Khadiga M. Sadek ${ }^{a}$, Wael Mamdouh ${ }^{\text {b, }}$, Shaymaa I. Habib ${ }^{a}$, Mervat EI Deftarc, A. Nour A. \\ Habib $^{\mathbf{a}}$

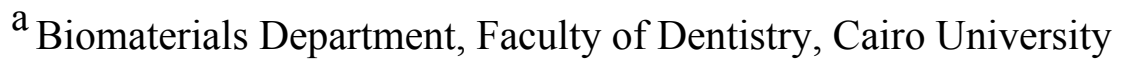 \\ ${ }^{b}$ Department of Chemistry, School of Sciences and Engineering (SSE), The American University \\ in Cairo (AUC) \\ ${ }^{\mathrm{c}}$ Pathology Department, Tissue Culture Unit, National Cancer Institute, Cairo University
}

Khadiga M. Sadek, Assistant lecturer of Dental Materials Science, Biomaterials Department, Faculty of Dentistry, Cairo University. Address: 11 El-Saraya St. - Manial, Cairo, 11562 Cairo, Egypt.

E-mail: Khadiga.sadek@dentistry.cu.edu.eg

Wael Mamdouh, Associate Professor of Nanotechnology, Department of Chemistry, School of Sciences and Engineering (SSE), The American University in Cairo (AUC). Address: AUC Avenue, New Cairo 11835 Egypt.

E-mail: wael mamdouh@aucegypt.edu

Shaymaa I. Habib, Assistant Professor of Dental Materials Science, Biomaterials Department, Faculty of Dentistry, Cairo University. Address: 11 El-Saraya St. - Manial, Cairo, 11562 Cairo, Egypt.

E-mail: shaymaa.habib@dentistry.cu.edu.eg 
Mervat El Deftar, Professor of Pathology, Pathology Department, Tissue Culture Unit, National Cancer Institute, Cairo University. Address: Kornish El-Nile, Fom El- Khaleg, 11796 Cairo, Egypt.

E-mail: mervat.eldeftar@nci.cu.edu.eg

A. Nour A. Habib, Professor of Dental Materials Science, Biomaterials Department, Faculty of Dentistry, Cairo University. Address: 11 El-Saraya St. - Manial, Cairo, 11562 Cairo, Egypt.

E-mail: nour.habib@dentistry.cu.edu.eg

*Corresponding Author: Wael Mamdouh, Ph.D. Associate Professor (tenured).

Leader, Biomedical Polymer Nanocomposites, Hydrogels, and Tissue Engineering Group Department of Chemistry, School of Sciences and Engineering (SSE), The American University in Cairo (AUC), AUC Avenue, P.O. Box 74, New Cairo 11835, Egypt

\section{Pilot study for the selection of the two PG extract concentrations:}

A pilot study was performed to determine the optimum PG concentrations that could be added to PCL and allow electrospinning of the obtained solutions. Therefore, random concentrations of pomegranate peel extract were tried; $1.8 \%, 3.9 \%, 5.9 \%, 7.7 \%, 11 \%, 18 \%, 28.5 \%$ and $36.2 \%$, and electrospinning was performed at 2 different flow rates $(0.5 \mathrm{ml} / \mathrm{h}$ and $1 \mathrm{ml} / \mathrm{h})$, at $23.5 \mathrm{KV}$, then analyzed by SEM. Selection was then based on certain fibers criteria (absence of beads in the fibers, no intermingling of fibers, fibers' uniformity, proper fiber diameter distribution, presence of porosity), in addition to the antioxidant activity and total phenolic content (TPC). Results of SEM for fiber selection criteria is shown in table S1 and figures (S1, S2,S3 and S4). 
Table S1: Different PG concentrations with the different electrospinning parameters and the criteria of fibers.

\begin{tabular}{|c|c|c|c|c|c|}
\hline PG\% & Flow rate & $\begin{array}{l}\text { Presence of } \\
\text { beads }\end{array}$ & $\begin{array}{c}\text { Intermingling of } \\
\text { fibers }\end{array}$ & $\begin{array}{c}\text { Mean Fiber } \\
\text { Diameter (nm) }\end{array}$ & $\begin{array}{c}\text { Uniformity of } \\
\text { fibers }\end{array}$ \\
\hline \multirow{2}{*}{$1.8 \%$} & $0.5 \mathrm{ml} / \mathrm{h}$ & Present & Present & 175.27 & Uniform \\
\hline & $1 \mathrm{ml} / \mathrm{h}$ & Present & Present & 180.28 & Uniform \\
\hline \multirow{2}{*}{$3.9 \%$} & $0.5 \mathrm{ml} / \mathrm{h}$ & Absent & Present & 161.07 & Uniform \\
\hline & $1 \mathrm{ml} / \mathrm{h}$ & Absent & Present & 154.62 & Uniform \\
\hline \multirow{2}{*}{$5.9 \%$} & $0.5 \mathrm{ml} / \mathrm{h}$ & Absent & Present (little) & 161.07 & Uniform \\
\hline & $1 \mathrm{ml} / \mathrm{h}$ & Present (little) & Absent & 143.56 & Uniform \\
\hline \multirow[t]{2}{*}{$7.7 \%$} & $0.5 \mathrm{ml} / \mathrm{h}$ & Present & Absent & 109.81 & Uniform \\
\hline & $1 \mathrm{ml} / \mathrm{h}$ & Present & Present & 107.9 & Not Uniform \\
\hline \multirow[t]{2}{*}{$11.2 \%$} & $0.5 \mathrm{ml} / \mathrm{h}$ & Absent & Absent & 147.97 & Uniform \\
\hline & $1 \mathrm{ml} / \mathrm{h}$ & Present & Absent & 126.12 & Uniform \\
\hline \multirow[t]{2}{*}{$18.1 \%$} & $0.5 \mathrm{ml} / \mathrm{h}$ & Absent & Absent & 156.08 & Uniform \\
\hline & $1 \mathrm{ml} / \mathrm{h}$ & Present & Absent & 200 & Uniform \\
\hline \multirow[t]{2}{*}{$28.5 \%$} & $0.5 \mathrm{ml} / \mathrm{h}$ & Present & Absent & 140.34 & Not Uniform \\
\hline & $1 \mathrm{ml} / \mathrm{h}$ & Present & Absent & 129.64 & Not Uniform \\
\hline $36.2 \%$ & \multicolumn{5}{|c|}{ No Electrospinning } \\
\hline
\end{tabular}



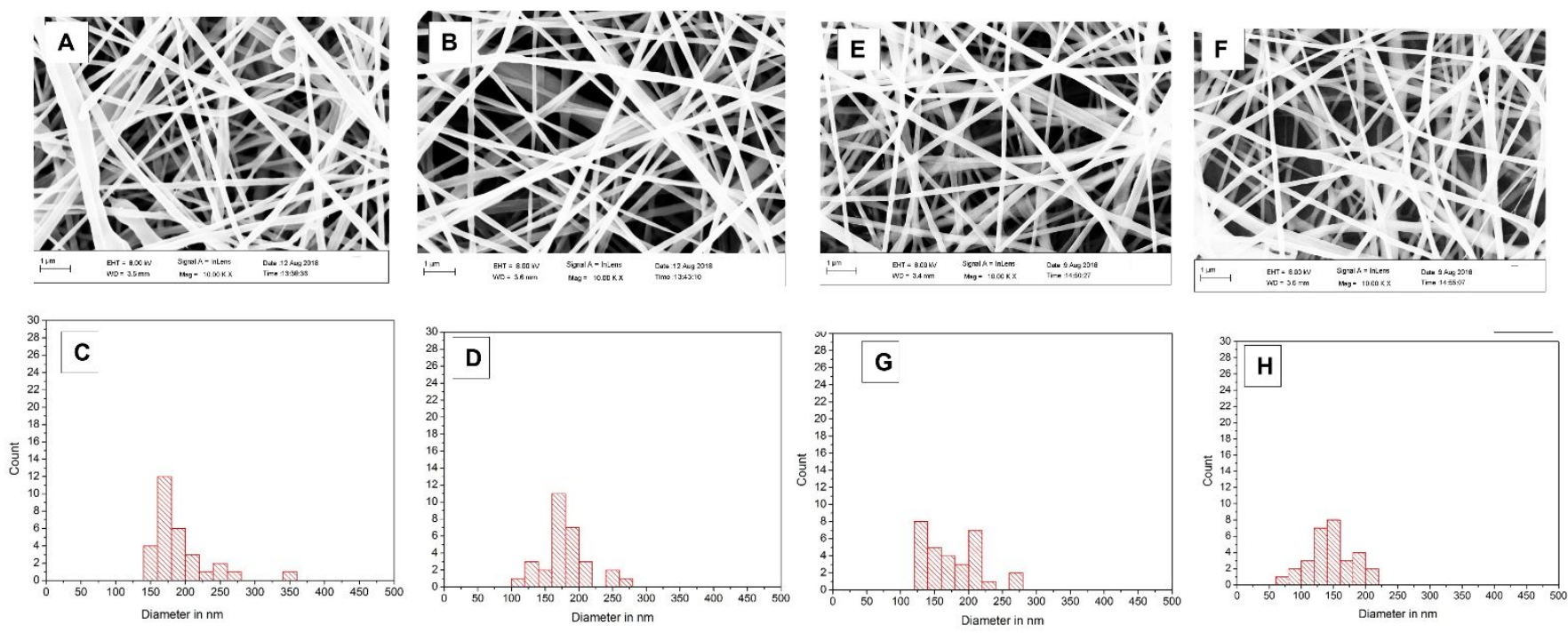

Figure S1: (A,B) SEM 10000x of 1.8\% PG added to 14\% PCL at flow rate $0.5 \mathrm{ml} / \mathrm{h}$ and 1 $\mathrm{ml} / \mathrm{h}$ respectively, (C,D) Histogram for fiber diameter distribution of $1.8 \%$ PG added to $14 \%$ PCL at flow rate $0.5 \mathrm{ml} / \mathrm{h}$ and $1 \mathrm{ml} / \mathrm{h}$ respectively. (E,F) SEM 10000x of 3.9\% PG added to $14 \% \mathrm{PCL}$ at flow rate $0.5 \mathrm{ml} / \mathrm{h}$ and $1 \mathrm{ml} / \mathrm{h}$ respectively, $(\mathrm{G}, \mathrm{H})$ Histogram for fiber diameter distribution of $3.9 \%$ PG added to $14 \%$ PCL at flow rate $0.5 \mathrm{ml} / \mathrm{h}$ and $1 \mathrm{ml} / \mathrm{h}$ respectively. 

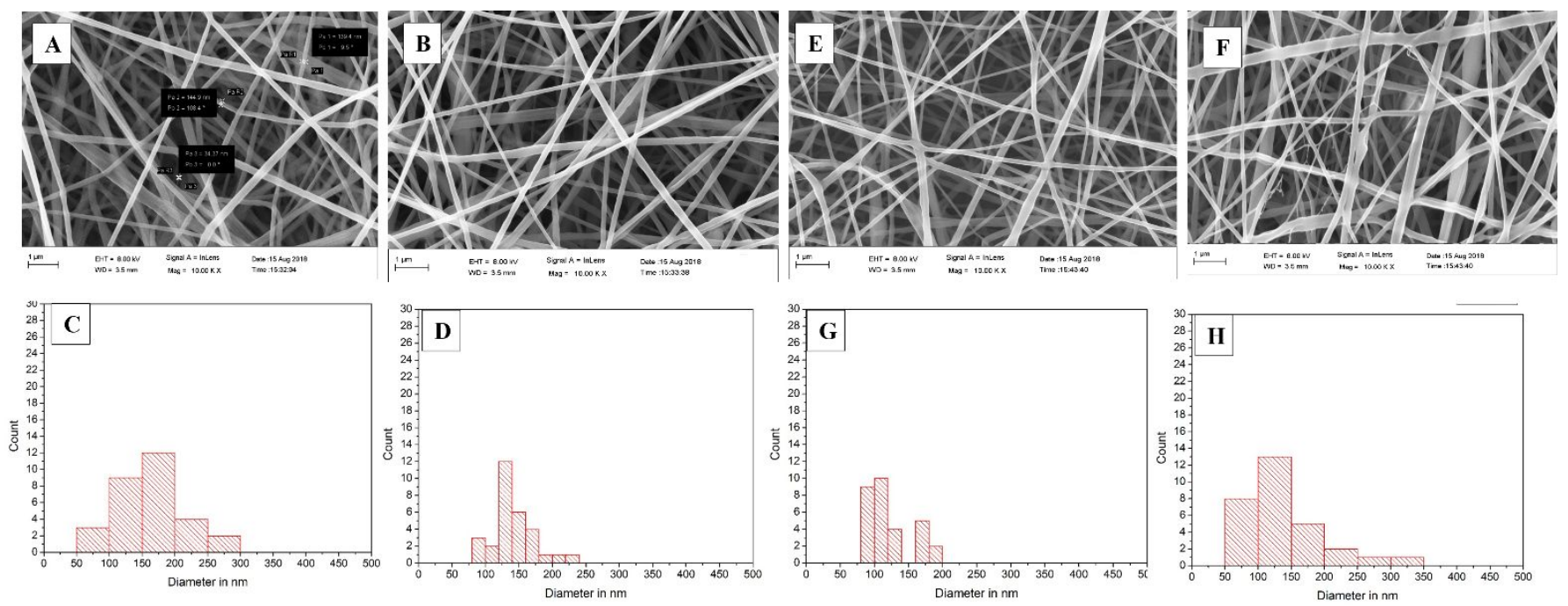

Figure S2: $(\mathrm{A}, \mathrm{B}) \mathrm{SEM} 10000 x$ of 5.9\% PG added to $14 \%$ PCL at flow rate $0.5 \mathrm{ml} / \mathrm{h}$ and 1 $\mathrm{ml} / \mathrm{h}$ respectively, (C,D) Histogram for fiber diameter distribution of 5.9\% PG added to $14 \%$ PCL at flow rate $0.5 \mathrm{ml} / \mathrm{h}$ and $1 \mathrm{ml} / \mathrm{h}$ respectively. (E,F) SEM 10000x of $7.7 \% \mathrm{PG}$ added to $14 \%$ PCL at flow rate $0.5 \mathrm{ml} / \mathrm{h}$ and $1 \mathrm{ml} / \mathrm{h}$ respectively, $(\mathrm{G}, \mathrm{H})$ Histogram for fiber diameter distribution of $7.7 \% \mathrm{PG}$ added to $14 \% \mathrm{PCL}$ at flow rate $0.5 \mathrm{ml} / \mathrm{h}$ and $1 \mathrm{ml} / \mathrm{h}$ respectively. 

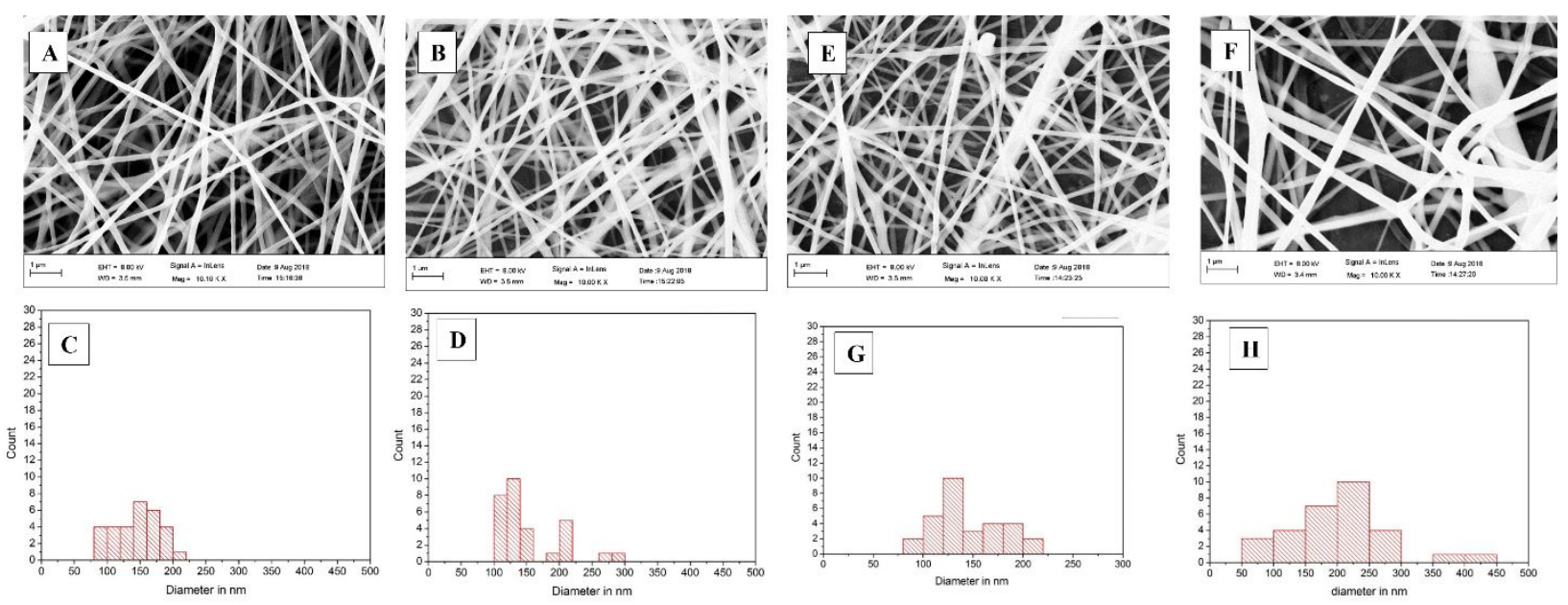

Figure S3: (A,B) SEM 10000x of 11.2\% PG added to 14\% PCL at flow rate $0.5 \mathrm{ml} / \mathrm{h}$ and 1 $\mathrm{ml} / \mathrm{h},(\mathrm{C}, \mathrm{D})$ Histogram for fiber diameter distribution of $11.2 \%$ PG added to $14 \%$ PCL at flow rate $0.5 \mathrm{ml} / \mathrm{h}$ and $1 \mathrm{ml} / \mathrm{h}$ (E,F) SEM 10000x of $18.1 \%$ PG added to $14 \%$ PCL at flow rate $0.5 \mathrm{ml} / \mathrm{h}$ and $1 \mathrm{ml} / \mathrm{h},(\mathrm{G}, \mathrm{H})$ Histogram for fiber diameter distribution of $18.1 \%$ PG added to $14 \%$ PCL at flow rate $0.5 \mathrm{ml} / \mathrm{h}$ and $1 \mathrm{ml} / \mathrm{h}$ 

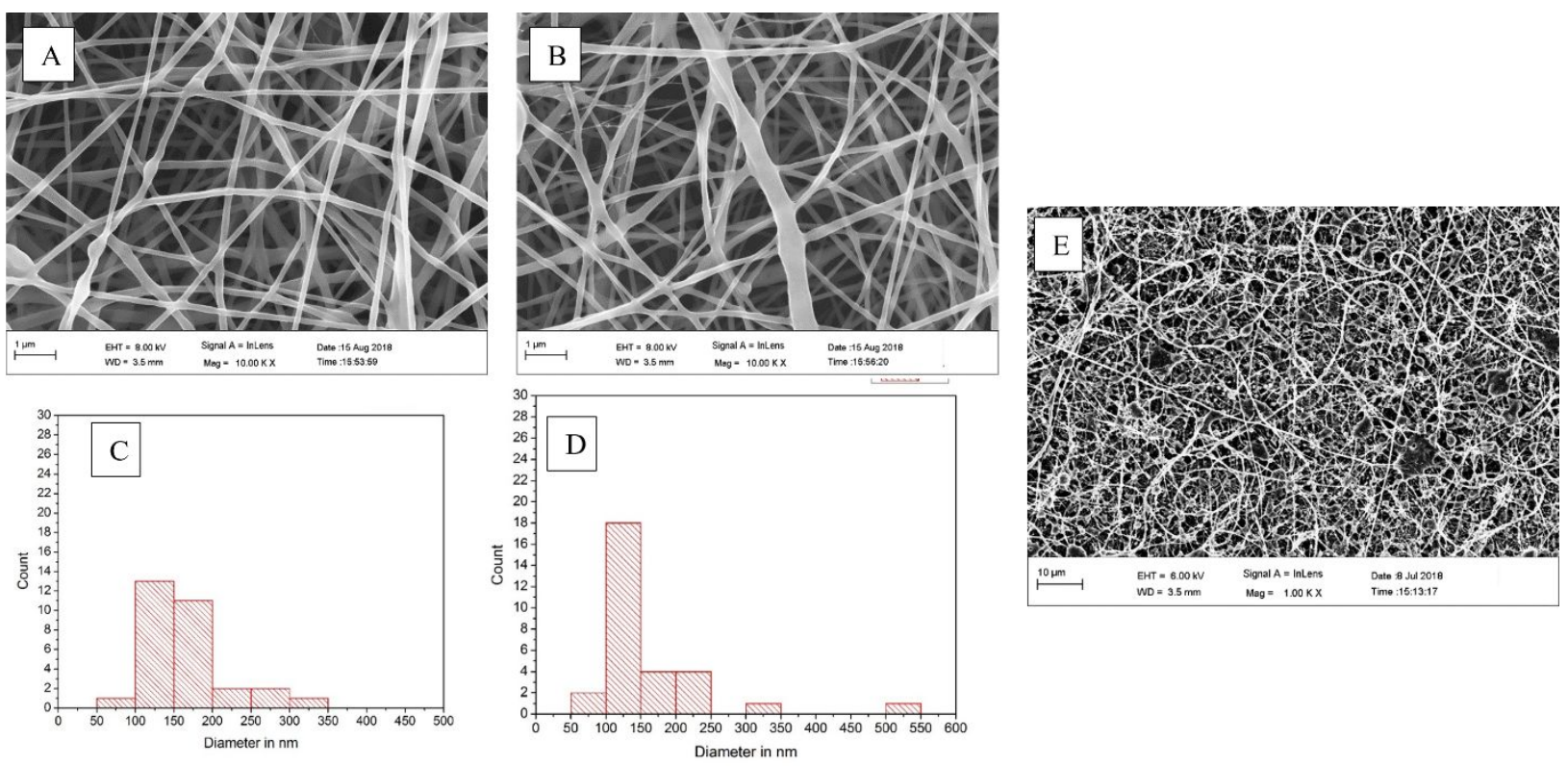

Figure S4: (A,B) SEM 10000x of 28.5\% PG added to 14\% PCL at flow rate $0.5 \mathrm{ml} / \mathrm{h}$ and 1 $\mathrm{ml} / \mathrm{h}$, (C,D) Histogram for fiber diameter distribution of $28.5 \%$ PG added to $14 \%$ PCL at flow rate $0.5 \mathrm{ml} / \mathrm{h}$ and $1 \mathrm{ml} / \mathrm{h}$ (E) SEM 1000x of $36.2 \%$ PG added to $14 \%$ PCL at flow rate $0.5 \mathrm{ml} / \mathrm{h}$ revealing droplets and no electrospinning.

Based on all the aforementioned criteria and observations detected from the SEM and histograms, five PG extract concentrations; 3.9\%, 7.7\%, 11.2\%, 18.1\% and 28.57\%, (electrospinned at 0.5 $\mathrm{ml} / \mathrm{h}$ ) were selected and were further investigated for the antioxidant test and Folin-Ciocalteu and results are shown in Figure S5. 


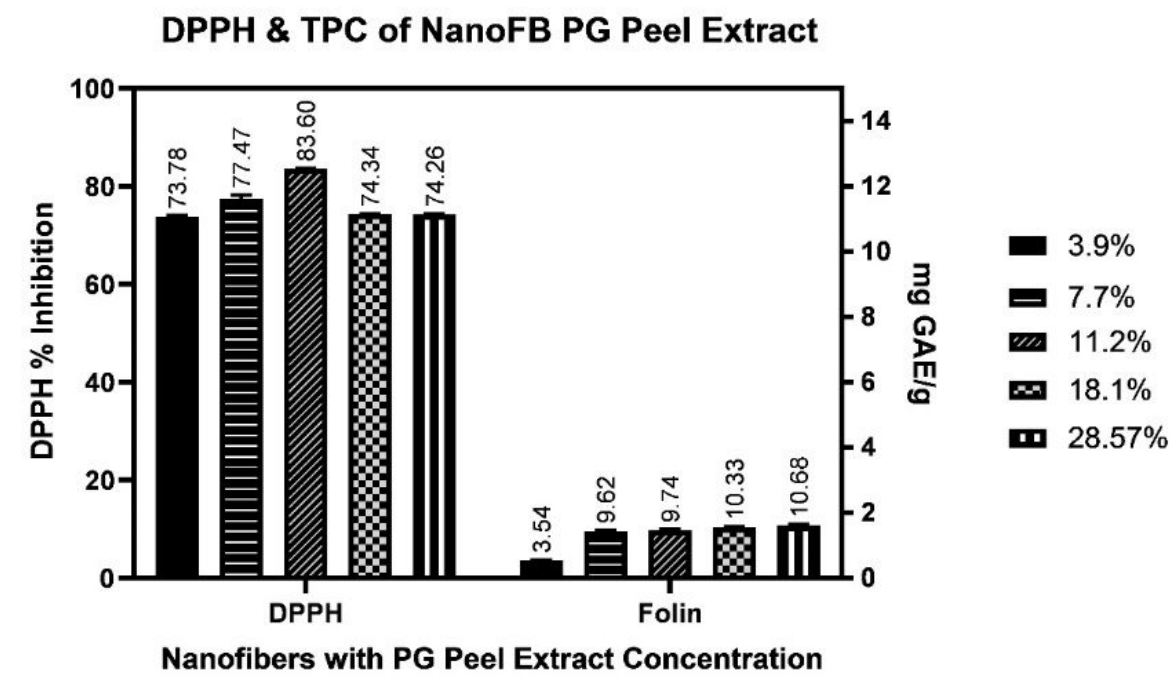

Figure S5: Antioxidant test and Folin-Ciocalteu test of nanofibers obtained from five solutions of different PG\% with 14\% PCL

Based on the results of this pilot study, the $11 \%$ and $18 \%$ PG concentration were selected to be tested and compared with the control solution as they had most of the needed criteria of the high quality nanofibers. Also they revealed almost the maximum DPPH scavenging activity \% and nearly the highest TPC.

\section{EDX Analysis of Pomegranate Extract:}

Elemental EDX analysis (JOEL; JCM-6000 PLUS, JED-2300 Analysis Station) was performed for the PG extract. It showed a high mass $\%$ of Carbon and Oxygen with traces of Silicon, Phosphorous, and Calcium, Figure S6. 


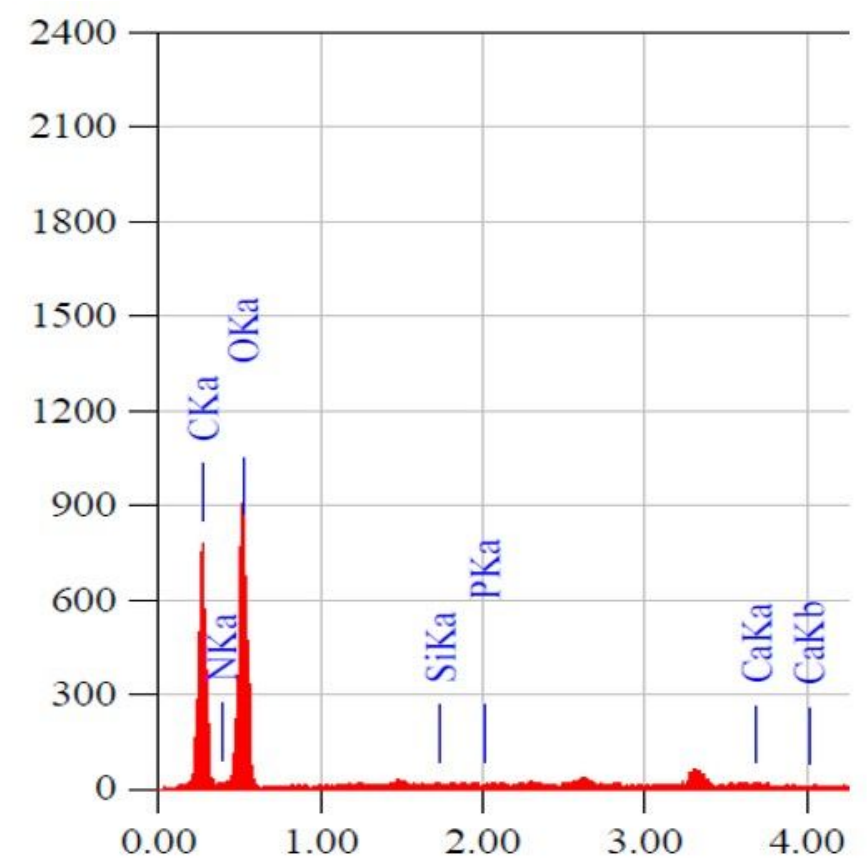

\begin{tabular}{|c|c|c|c|c|c|c|c|}
\hline \multicolumn{7}{|c|}{ PG Ext. } \\
\hline Element & $\mathrm{C}$ & $\mathrm{N}$ & $\mathrm{O}$ & $\mathrm{Si}$ & $\mathrm{P}$ & $\mathrm{Ca}$ & Total \\
\hline Mass \% & 67.32 & 1.63 & 30.84 & 0.04 & 0.02 & 0.16 & 100 \\
\hline $\begin{array}{c}\text { Atomic } \\
\%\end{array}$ & 73.22 & 1.52 & 25.18 & 0.02 & 0.01 & 0.05 & 100 \\
\hline
\end{tabular}

Figure S6: EDX analysis of PG extract 